\title{
EFEKTIVITAS PEMBELAJARAN KEWIRAUSAHAAN
}

\section{(EFFECTIVENESS OF LEARNING ENTREPRENEURSHIP)}

\author{
Oleh: \\ Jayadi'), Yuli Triastuti'i), Sri Lestari Prasilowati ${ }^{3)}$ \\ Sekolah Tinggi Ilmu Ekonomi IPWI Jakarta1,2) \\ djayadi.ipwija@yahoo.com ${ }^{1}$,yulitrias@gmail.com²),widiyantoterry@yahoo.com ${ }^{3}$ )
}

Submit: 6 Feb 2020 Review: 10 Apr 2020 Accept: 25 Apr $2020 \quad$ Publish: 30 Apr 2020

\begin{abstract}
The study was conducted with the aim of finding out whether there were differences in attitudes, motivation and entrepreneurial interests of STIE IPWIJA students before and after receiving entrepreneurship learning. The research was conducted at the STIE IPWIJA Campus in 2019. The research method used was a comparative study with the Quasi Experiment (One Group Pretest and Postest Design) design. The population in this study were students who were taking Entrepreneurship courses totally 225 students. The research sample used was 150 students taken by the Cluster Random Sampling technique. Research data were collected through a closed questionnaire given to students before and after taking entrepreneurship courses. The research data were processed by descriptive and inferential analysis using the correlated test formula ( $t$-test) of two samples. Data processing using SPSS software. The results showed that: (1) There were differences in entrepreneurship attitudes of STIE IPWIJA students before and after receiving entrepreneurship course, (2) There were differences in entrepreneurship motivation of STIE IPWIJA students before and after receiving entrepreneurship course, (3) There were no differences in entrepreneurial interest in STIE IPWIJA students before and after receiving entrepreneurship course.
\end{abstract}

Keywords:

Effectiveness, Entrepreneurship Learning, Motivation, Attitudes, and Entrepreneurial Interest.

\section{ABSTRAK}

Penelitian dilaksanakan dengan tujuan untuk mengetahui apakah ada perbedaan sikap, motivasi dan minat berwirausaha mahasiswa STIE IPWIJA sebelum dan sesudah mendapat pembelajaran kewirausahaan. Penelitian dilaksanakan di Kampus STIE IPWIJA Tahun 2019. Metode penelitian yang digunakan adalah studi komparatif dengan desain Quasi Experiment (One Group Pretest and Postest Design). Populasi dalam penelitian adalah mahasiswa yang sedang menempuh mata kuliah Kewirausahaan berjumlah 225. Sampel penelitian yang digunakan sebanyak 150 mahasiswa yang diambil dengan teknik Cluster Random Sampling. Data penelitian dikumpulkan melalui kuesioner tertutup yang diberikan kepada mahasiswa sebelum dan sesudah menempuh mata kuliah kewirausahaan. Data penelitian diolah dengan analisis deskriptif dan inferensial menggunakan rumus uji beda (t-test) dua sampel yang berkorelasi. Pengolahan data menggunakan bantuan software SPSS. 
Hasil penelitian menunjukkan bahwa: (1) Ada perbedaan sikap berwirausaha mahasiswa STIE IPWIJA sebelum dan sesudah mendapatkan pembelajaran kewirausahaan, (2) Ada perbedaan motivasi berwirausaha mahasiswa STIE IPWIJA sebelum dan sesudah mendapatkan pembelajaran kewirausahaan, (3) Tidak ada perbedaan minat berwirausaha mahasiswa STIE IPWIJA sebelum dan sesudah mendapatkan pembelajaran kewirausahaan.

Kata kunci:

Efektivitas, Pembelajaran Kewirausahaan, Motivasi, Sikap, dan Minat Berwirausaha.

\section{PENDAHULUAN}

Ketangguhan perekonomian sebuah negara salah satu indikatornya bisa dilihat dari rasio jumlah pengusaha dengan jumlah penduduknya. Berdasarkan data dari Asosiasi Pengusaha Indonesia (Apindo) pada tahun 2018, jumlah wirausaha di Indonesia baru mencapai angka 3,1\% dari jumlah penduduk usia produktif. Jumlah ini terbilang minim dibanding tingkat wirausaha di negaranegara maju yang bisa mencapai $14 \%$ (CNN Indonesia). Berdasarkan data tersebut maka sudah dapat dipastikan bahwa tingkat pengangguran di Indonesia sangatlah tinggi. Pengangguran terjadi karena perbandingan antar pencari pekerjaan di segala level pendidikan mulai dari tingkat SMP sampai dengan Perguruan Tinggi tidak sebanding dengan pekerjaan yang tersedia. Berdasarkan data BPS tahun 2018 tingkat pengangguran terbuka di Indonesia masih dikisaran pada tingkat 5,34\% atau sejumlah 7 juta dari jumlah angkatan kerja sebesar 131,01 juta (www.bps.go.id)

Salah satu upaya untuk mengurangi pengangguran adalah dengan berwirausaha. Dengan berwirausaha maka dapat menciptakan lapangan pekerjaan yang luas, tidak bergantung kepada orang lain dalam mendapatkan pekerjaan sehingga dapat mengurangi tingkat pengangguran. Masyarakat harus disadarkan dengan pentingnya meningkatkan minat berwirausaha, dan ternyata tidak mudah untuk menyadarkan kepada masyarakat untuk berwirausaha. Minat dapat diartikan sebagai rasa senang atau ketertarikan terhadap sesuatu. Menurut Fu'adi (2009:93) minat berwirausaha adalah keinginan, ketertarikan, serta kesediaan individu melalui ide-ide yang dimiliki untuk bekerja keras atau berkemauan keras untuk berusaha memenuhi kebutuhan hidupnya, tanpa merasa takut dengan resiko yang akan terjadi, dapat menerima tantangan, percaya diri, kreatif, dan inovatif serta mempunyai kemampuan dan keterampilan untuk memenuhi kebutuhan. Minat untuk mulai berwirausaha pada mahasiswa sebenarnya sudah cukup tinggi, namun bayangan kegagalan, tidak memiliki modal yang cukup dan tidak memiliki waktu untuk fokus dalam mengembangkan usahanya menjadi risiko yang menghambat mahasiswa untuk memulai usahanya sendiri

Kalau dilihat dari gender biasanya laki-laki lebih suka tantangan dan memilih berwirausaha, hal ini sejalan penelitian yang dilakukan oleh Retno Budi Lestari dan Trinadi Wijaya (2012) bahwa rata-rata minat berwirausaha mahasiswa laki-laki lebih tinggi dari mahasiswa perempuan. Faktor-faktor lain yang mempengaruhi minat berwirausaha antara lain, ekspektasi pendapatan atau penghasilan, latar belakang keluarga, dan pendidikan kewirausahaan. Hasil penelitian yang dilakukan oleh Paulus Patria Adhitama 
(2014), meyimpulkan bahwa: (1) semakin tinggi ekspektasi pendapatan atau penghasilan maka akan semakin meningkatkan minat berwirausaha mahasiswa, (2) semakin mendukung lingkungan keluarga akan semakin meningkatkan minat berwirausaha mahasiswa, (3) semakin baik pendidikan kewirausahaan maka akan semakin meningkatakan minat berwirausaha mahasiswa.

Sekolah Tinggi Ilmu Ekonomi IPWI Jakarta merupakan perguruan tinggi swasta yang mempunyai visi kepemimpinan dan kewirausahaan. Untuk mengembangkan jiwa dan meningkatkan motivasi dan minat berwirausaha kepada setiap mahasiswa maka diberikan pembelajaran mata kuliah kewirausahaan pada semester enam.

\section{TUJUAN PENELITIAN}

Untuk mengetahui apakah ada perbedaan sikap, motivasi dan minat berwirausaha mahasiswa STIE IPWIJA sebelum dan sesudah mendapat pembelajaran kewirausahaan.

\section{TELAAH LITERATUR DAN PENGEMBANGAN HIPOTESIS} Pembelajaran Kewirausahaan

Pengetahuan kewirausahaan memiliki peran yang sangat penting dalam aspek kehidupan manusia. Secara umum pengetahuan didefinisikan sebagai segala sesuatu yang diketahui oleh seseorang. Pengetahuan memungkinkan manusia mengembangkan keterampilan yang berguna bagi kehidupannya. Demikian halnya dengan pengetahuan kewirausahaan juga merupakan faktor yang penting dalam kegiatan kewirausahaan. Melalui pembelajaran kewirausahaan maka akan diperolehlah yang namanya pengetahuan kewirausahaan. Dengan adanya pembelajaran kewirausahaan diharapkan mampu mengurangi tingginya angka pengangguran, khususnya dari kalangan terdidik (Sarjana dan Diploma ). Ketua Center of Entrepreneur Development (CED) Universitas Gadjah Mada Edi Suryanto, menyatakan bahwa kewirausahaan menjadi suatu hal yang harus diberikan di perguruan tinggi. Dengan adanya pembelajaran kewirausahaan diharapkan mampu mengurangi tingginya angka pengangguran, khususnya dari kalangan terdidik (Sarjana dan Diploma) (www.ugm.ac.id).

Dengan adanya pembelajaran kewirausahaan seseorang dapat dengan mudah mengetahui hal-hal apa saja yang harus dilakukan ketika dia terjun langsung sebagai wirausaha. Penelitian yang dilakukan oleh Muchammad Arif Mustofa (2014) menyatakan bahwa: (a) terdapat pengaruh positif dan signifikan pengetahuan kewirausahaan, self efficacy, dan karakter wirausaha secara bersamasama terhadap minat berwirausaha, (b) terdapat pengaruh positif dan signifikan pengetahuan kewirausahaan terhadap minat berwirausaha, (c) terdapat pengaruh positif dan signifikan pengaruh self efficacy terhadap minat berwirausaha, (d) terdapat pengaruh positif dan signifikan pengaruh karakter wirausaha terhadap minat berwirausaha. Menurut Saiman (2009: 43) kewirausahaan adalah hal-hal atau upayaupaya yang berkaitan dengan penciptaan kegiatan atau usaha atau aktivitas bisnis atas dasar kemauan sendiri dan atau kemampuan sendiri. Kemudian menurut Lambing \& Kuehl dalam (Hendro, 2011: 30) kewirausahaan adalah suatu usaha yang kreatif yang membangun suatu value dari yang belum ada menjadi ada dan dapat dinikmati oleh orang banyak. Dapat disimpulkan bahwa kewirausahaan merupakan suatu usaha atau kegiatan 
yang dilakukan oleh seseorang secara sadar untuk menciptakan, mengubah atau menambah nilai suatu barang atau jasa dengan berharap memperoleh keuntungan dan siap menanggung risiko yang ada.

Terdapat beberapa karakteristik dari wirausaha yang berhasil memiliki sifatsifat yang dikenal dengan istilah $10 \mathrm{D}$, dikemukakan oleh Bygrafe dalam Buchari Alma (2009: 58), yaitu :

a. Dream, wirausaha mempunyai visi tentang kenginannya di masa depan dalam kehidupan pribadi dan usahanya dan berusaha untuk menggunakan kemampuannya untuk mewujudkan visi tersebut.

b. Decisivenese, wirausaha tidak bekerja lambat. Keputusan yang diambilnya merupakan keputusan yang cepat namun, tetap penuh perhitungan. Kecepatan dan ketepannya dalam mengambil keputusan merupakan faktor utama dalam kesuksesan bisnis.

c. Doers, setelah keputusan diambil wirausaha langsung mengambil tindakan lebih lanjut. Kegiatannya di lakukan dengan cepat tanpa ditunda.

d. Determination, kegiatan yang dilakukan oleh wirausaha dilakukan dengan penuh perhatian. Ia memiliki sikap tanggung jawab dan tidak menyerah pada halangan apapun.

e. Dedication, wirausaha mendedikasikan dirinya pada bisnis yang dijalankan dengan sungguh-sungguh tidak jarang mereka mengorbankan keluarganya dan kesenangan dirinya untuk sementara waktu.

f. Devotion, wirausaha mencintai pekerjaan dan produk yang dihasilkannya. Kecintaannya pada pekerjaan membuat ia terdorong untuk mencapai hasil yang diinginkan.

g. Details, wirausaha memperhatikan segala faktor yang ada tanpa mengabaikan faktor sekecil apapun yang dapat menghambat berjalannya bisnis.

h. Destiny, wirausaha bertanggung jawab pada nasib dan tujuan yang ingin dicapai. Ia menyukai kebebasan tanpa bergantung pada orang lain.

i. Dollars, motivasi wirausaha tidak hanya untuk mendapatkan uang. Melainkan uang digunakan sebagai ukuran kesuksesan yang telah diraihnya. Ia merasa layak untuk mendapatkan keuntungan jika bisnisnya sudah dapat berjalan dengan sukses.

j. Distribute, wirausaha bersedia mendistribusikan kepemilikan bisnisnya pada orang yang telah dipercaya. Orang-orang kepercayaannya merupakan orang yang memiliki semangat dan jalan pikiran yang sama.

\section{Sikap Berwirausaha}

Sikap Berwirausaha merupakan bentuk dari sikap dan mental seorang enterpreneur. Definisi sikap merupakan konsepsi yang bersifat abstrak tentang pemahaman perilaku manusia. Seseorang akan lebih mudah memahami perilaku orang lain apabila terlebih dahulu mengetahui sikap atau latar belakang orang tersebut. Menurut Mar'at (2000: 21) sikap adalah tingkatan afeksi (perasaan), baik yang bersifat positif maupun negatif dalam hubungannya dengan objek psikologi. Dengan demikian perasaan dalam merespon suatu objek dapat positif yaitu perasaan senang, menerima, terbuka dan lain-lain dan dapat juga bersifat negatif yaitu perasaan tidak senang, tidak menerima, tidak terbuka dan lain-lain

Untuk menjadi seorang wirausahawan harus memiliki sikap mental berani tetapi dengan perhitungan yang matang sangat membantu keberhasilannya. Perolehan 
hasil pendidikan formal juga membantu, tetapi penelitian Schriciber, keberhasilan seseorang yang ditentukan oleh pendidikan formal hanya $15 \%$ dan selebihnya $85 \%$ ditentukan oleh sikap mental atau kepribadian (Buchari Alma, 2009: 18). Ada beberapa faktor yang dapat mempengaruhi pembentukan sikap berwirausaha dikemukakan Azwar (2017: 30) antara lain: pengalaman pribadi, kebudayaan, pengaruh orang lain yang dianggap penting, serta faktor emosi dalam diri individu

Kepemilikan sikap wirausaha dapat dilihat dengan beberapa ciri utama, di antaranya kemauan keras untuk mencapai tujuan dan kebutuhan hidup, memiliki keyakinan kuat atas kekuatan diri, jujur dan tanggung jawab, ketahan fisik dan mental, ketekunan dan keuletan dalam bekerja dan berusaha, pemikiran kreatif dan konstruktif, berorientasi kemasa depan dan berani mengambil resiko. Seorang wirausaha harus bersikap modern artinya harus bisa terbuka pada pengalaman-pengalaman baru sehingga menjadi siap untuk merespon segala peluang, dan tanggap terhadap perubahan sosial misalnya dalam mengubah standar hidupnya. Karakteristik sikap berwirausaha menurut M. Scarborough dan Thomas W. Zimmerer dalam Suryana (2011: 23) identifikasi sikap seorang wirausahawan yang dapat diangkat dari kegiatannya sehari-hari, sebagai berikut: disiplin, komitmen tinggi, jujur, kreatif, mandiri, dan realistis.

\section{Motivasi Berwirausaha}

Dalam Kamus Besar Bahasa Indonesia, motivasi diartikan sebagai suatu dorongan dalam diri seseorang baik disadari atau tidak untuk melakukan suatu tindakan dan tujuan tertentu. Selain itu motivasi juga merupakan suatu usaha yang dapat menyebabkan seseorang atau kelompok melakukan kegiatan tertentu karena ingin mendapat kepuasan. Ciri-ciri inidividu yang menunjukkan orientasi tinggi antara lain bersedia menerima resiko yang relatif tinggi, keinginan untuk mendapatkan umpan balik tentang hasil kerja mereka, keinginan mendapatkan tanggung jawab pemecahan masalah. n$\mathrm{ACH}$ adalah motivasi untuk berprestasi, karena itu karyawan akan berusaha mencapai prestasi tertingginya, pencapaian tujuan tersebut bersifat realistis tetapi menantang, dan kemajuan dalam pekerjaan. Karyawan perlu mendapat umpan balik dari lingkungannya sebagai bentuk pengakuan terhadap prestasinya tersebut. Kebutuhan ini pada teori Maslow terletak antara kebutuhan akan penghargaan dan kebutuhan aktualisasi diri. Individu yang mempunyai kebutuhan afiliasi yang tinggi umumnya berhasil dalam pekerjaan yang memerlukan interaksi sosial yang tinggi.

Motivasi berada dalam diri manusia yang tidak terlihat dari luar. Kemudian apa yang disampaikan King (2010: 64) motivasi adalah kekuatan yang menggerakkan seseorang untuk berperilaku, berpikir, dan merasa seperti yang mereka lakukan. Sofyan \& Uno (2004: 3) menyampaikan motivasi merupakan dorongan dasar yang menggerakkan seseorang untuk bertingkah laku. Motivasi berwirausaha semakin tinggi motivasi seseorang akan semakin mudah menumbuhkan minat orang tersebut, dengan adanya minat maka akan mendorong atau memicu daya tarik seseorang. Riyanti menyatakan bahwa motivasi berwirausaha adalah dorongan teknis yang sangat kuat dalam diri individu untuk mempersiapkan diri dalam bekerja, memiliki kesadaran bahwa wirausaha bersangkut paut dengan dirinya, sehingga ia lebih banyak memberikan perhatian dan lebih senang melakukan kegiatan kewirausahaan secara 
mandiri, percaya pada diri sendiri, berorientasi ke masa depan, disertai dengan hasrat untuk berprestasi pada bidangnya berdasarkan kemampuan, kekuatan, dan keterampilan yang dimilikinya dan perencanaan yang tepat (Mubarak 2013: 15).

Menurut Suryana \& Bayu (2010: 102117) motivasi memiliki tujuan untuk dapat menunjang karakteristik dari seorang wirausaha antara lain:

1. Pekerja keras. Kerja keras merupakan modal dasar untuk keberhasilan seseorang (wirausahawan). Kerja keras atau etos kerja keras sering dianggap sebagai mimpi kuno dan seharusnya diganti, tetapi hardwork and smartwork tidak dapat dipisahkan lagi. Jadi selain kerja keras, efektif dalam bekerja merupakan dua hal yang tidak dapat dipisahkan.

2. Tidak pernah menyerah. Menjadi seorang wirausaha, tidak diperkenankan memiliki sifat yang mudah menyerah. Banyak wirausahawan yang telah berhasil dan sukses setelah wirausahawan tersebut melewati tantangan dan tetap berjuang untuk meraih kesukesan.

3. Memiliki semangat. Seorang wirausahawan harus selalu gembira di dalam setiap situasi. Kegembiraan tersebut yang menjadi semangat untuk menjadi kekuatan. Dengan semangat dan kekuatan akan menumbuhkan keberanian yang akan mendukung keberhasilan.

4. Memiliki komitmen. Komitmen merupakan proses pada individu untuk menyesuaikan dengan aturan, nilai dan tujuan dari perusahaan. Seorang wirausaha yang baik akan memiliki komitmen yang kuat untuk memberikan tenaga dan tanggung jawab yang dapat memajukan bisnisnya.
Berdasarkan uraian di atas, dapat disimpulkan bahwa motivasi berwirausaha merupakan dorongan psikologis dari dalam maupun luar diri seseorang untuk bisa melakukan wirausaha. Dengan adanya dorongan tersebut, seseorang dapat menentukan usaha apa yang akan dilakukan sekaligus juga dapat menentukan nasibnya dimasa depan.

\section{Minat Berwirausaha}

Minat wirausaha tidak hanya keinginan dari dalam diri saja tetapi harus melihat ke depan dalam potensi mendirikan usaha. Minat berwirausaha merupakan suatu keinginan, ketertarikan serta kesediaan untuk bekerja keras atau berkemauan keras dengan adanya pemusatan perhatian untuk berusaha memenuhi kebutuhan hidupnya tanpa merasa takut akan resiko yang akan dihadapi, senantiasa belajar dari kegagalan yang dialami, serta mengembangkan usaha yang diciptakannya.

Menurut Slameto (2003: 180) minat adalah suatu rasa lebih suka dan rasa ketertarikan pada suatu hal atau aktivitas, tanpa ada yang menyuruh. Minat berwirausaha tidak dibawa sejak lahir tapi tumbuh dan berkembang sesuai dengan faktor-faktor yang mempengaruhi. Faktor yang mempengaruhi tumbuhnya keputusan untuk berwirausaha merupakan hasil interaksi dari beberapa faktor yaitu karakter kepribadian seseorang dan lingkungannya (Bygrave dalam Budi Wahyono, 2014).

Menurut Johanes dalam Bimo Walgito (1999: 35), minat dapat digolongkan menjadi dua, yaitu minat intrinsik dan ekstrinsik. Minat intrinsik timbul karena adanya pengaruh dari sikap, pesepsi, prestasi belajar, bakat, motivasi, jenis kelamin dan harapan bekerja. Sedangkan minat ekstrinsik merupakan minat yang 
timbul pada diri seseorang karena adanya pengaruh dari luar seseorang tersebut. Minat ekstrinsik timbul karena adanya pengaruh latar belakang status sosial ekonomi orang tua, minat orang tua, informasi, lingkungan dan lain sebagainya. Minat berwirausaha juga akan timbul ketika seseorang telah banyak mendapatkan informasi tentang dunia kewirausahaan baik dari pengalaman orang lain maupun dari buku kewirausahaan. Seseorang yang telah senang dan tertarik untuk menjadi wirausaha ingin lebih mengetahui tentang kegiatan kewirausahaan. Dengan meningkatnya minat berwirausaha, seseorang akan memiliki kesempatan untuk ikut serta dalam memajukan perekonomian diri sendiri maupun masyarakat dengan cara membuka lapangan pekerjaan.

Minat berwirausaha merupakan rasa senang dan tertarik dalam melakukan aktivitas berwirausaha. Seseorang yang telah memiliki minat dalam berwirausaha akan lebih siap dalam menanggung berbagai risiko yang mungkin terjadi ketika seseorang tersebut telah memutuskan untuk memulai berwirausaha. Minat berwirausaha juga akan timbul ketika seseorang telah banyak mendapatkan informasi tentang dunia kewirausahaan baik dari pengalaman orang lain maupun dari buku kewirausahaan. Seseorang yang telah senang dan tertarik untuk menjadi wirausaha ingin lebih mengetahui tentang kegiatan kewirausahaan. Dengan meningkatnya minat berwirausaha, seseorang akan memiliki kesempatan untuk ikut serta dalam memajukan perekonomian diri sendiri maupun masyarakat dengan cara membuka lapangan pekerjaan.

\section{Kerangka Penelitian}

Kerangka efektifitas pembelajaran kewirausahaan terhadap sikap, motivasi dan minat berwirausaha dapat digambarkan sebagai berikut :

\begin{tabular}{|lll|}
\hline Pretest & Treatment & Posttest \\
$\mathbf{T}_{1}$ & $\mathbf{X}$ & $\mathbf{T}_{\mathbf{2}}$ \\
- Sikap & (Pembelajaran & - Sikap \\
- Motivasi & Kewirausahaan) & - Motivasi \\
- Minat & & - Minat \\
\hline
\end{tabular}

Pembelajaran kewirausahaan merupakan upaya pengenalan dunia usaha yang meliputi aspek wirausaha dan keterampilan mengelola usaha yang diperoleh mahasiswa dari proses perkuliahan di kampus. Melalui pembelajaran kewirausahaan mahasiswa akan mendapatkan gambaran dan bekal mengenai kewirausahaan yang nantinya dapat dijadikan bahan pertimbangan mahasiswa untuk menentukan masa depannya. Pembelajaran kewirausahaan yang tepat sasaran akan dapat merubah mindset seorang mahasiswa dalam hal sikap, motivasi dan minat berwirausaha. Hal ini didukung hasil penelitian yang menyatakan bahwa pendidikan kewirausahaan berpengaruh terhadap sikap berwirausaha mahasiswa Fakultas Ekonomi Universitas Muhammadiyah Surabaya (Andhika Wahyudiono, 2013). Hasil penelitian oleh Reza Fahmi (2012) menyimpulkan bahwa pembelajaran kewirausahaan berpengaruh signifikan terhadap motivasi berwirausaha mahasiswa Fakultas Ushuludin IAIN Imam Bonjol Padang. Penelitian lain yang dilakukan oleh Arwan Daniel dan Muslihkah Dwihartanti (2017) menunjukkan bahwa pembelajaran kewirausahaan memiliki pengaruh yang signifikan sebesar 20,1\% terhadap minat berwirausaha mahasiswa Prodi Pendidikan Administrasi Perkantoran UNY. 
Mahasiswa yang memiliki minat yang besar dalam berwirausaha, tanpa ada yang menyuruh akan dengan sendirinya melakukan wirausaha untuk mendapatkan kesenangannya tersebut. Minat berwirausaha tidak selalu di bawa dari lahir, namun minat tersebut dapat ditumbuhkan dengan pengetahuan dan pelatihan. Dengan demikian, semakin kuat kesenangan dalam melakukan kewirausaahan, akan semakin kuat minat seseorang dalam berwirausaha. Menumbuhkan minat dalam berwirausaha dapat juga dilakukan melalui beberapa faktor antara lain pengetahuan kewirausahaan, motivasi berwirausaha dan lingkungan keluarga.

Berdasarkan kerangka pemikiran maka dapat diduga bahwa mahasiswa akan berbeda sikapnya, motivasinya dan minatnya dalam berwirausaha.

H1: Ada perbedaan sikap berwirausaha mahasiswa sebelum dan sesudah pembelajaran kewirausahaan.

H2: Ada perbedaan motivasi berwirausaha mahasiswa sebelum dan sesudah pembelajaran kewirausahaan.

H3: Ada perbedaan minat berwirausaha mahasiswa sebelum dan sesudah pembelajaran kewirausahaan.

\section{METODE PENELITIAN Sampel Penelitian}

Sampel penelitian yang digunakan sebanyak 150 mahasiswa dari populasi berjumlah 225 yang diambil dengan cara Cluster Random Sampling. Sebanyak 150 responden yang terpilih menjadi sampel diberikan kuesioner tertutup dengan skala penilaian $1 \mathrm{~s} / \mathrm{d}$ 5. Pengisian kuesioner diberikan dua tahap, yaitu sebelum dan setelah mengikuti pembelajaran kewirausahaan. Sebelum kuesioner digunakan dilakukan ujicoba terlebih dulu kepada 30 mahasiswa diluar sampel yang terpilih.

\section{Desain Penelitian}

Metode penelitian yang digunakan adalah studi komparatif dengan desain Quasi Experiment (One Group Pretest and Postest Design). Adapun model penelitiannya sebagai berikut :

$\mathbf{T}_{\mathbf{1}}$

$\mathbf{X}$

$\mathbf{T}_{2}$

Sumber : Sumadi Suryabrata, 2002: 41

Keterangan :

T1: Pretest, pengukuran sebelum perlakuan

X: Treatment/Perlakuan

T2: Posttest, pengukuran setelah perlakuan

\section{Operasionalisasi Variabel}

Variabel penelitian secara operasional variabel sebagai berikut :

Tabel 1

\begin{tabular}{|c|c|c|}
\hline Variabel/Konsep & Indibator & Skaln \\
\hline 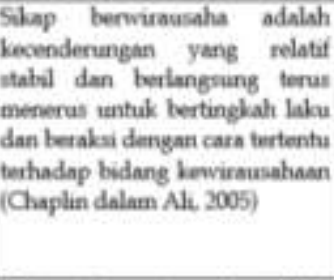 & $\begin{array}{l}\text { - Percaya dini } \\
\text { - Memilia inisiatif } \\
\text { - Memiliki motaf } \\
\text { berperestasi } \\
\text { - Memilik } \\
\text { kepemimpinan } \\
\text { - Rerani mengambil } \\
\text { resiko } \\
\text { - Fenuh perhitungan }\end{array}$ & $\begin{array}{l}\text { Interval } \\
1 \leqslant / d s\end{array}$ \\
\hline 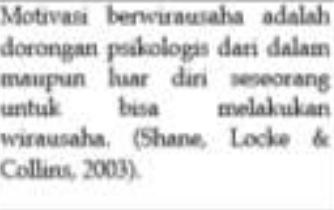 & $\begin{array}{l}\text { - Kebutuhan akan } \\
\text { prestasi } \\
\text { - Peneamibilan resibo } \\
\text { - Potensi ketidalpastian } \\
\text { - Kepercayan dini } \\
\text { - Kenginan yang haat } \\
\text { - Kreativitas }\end{array}$ & $\begin{array}{l}\text { lnterval } \\
1 \mathrm{~s} / \mathrm{d} 5\end{array}$ \\
\hline 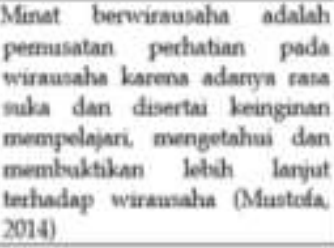 & $\begin{array}{l}\text { - Tudak tergantung pada } \\
\text { orang lain } \\
\text { - Dopat membantu } \\
\text { linghangan soiaal } \\
\text { - Senang twenjadi } \\
\text { wirauiaha }\end{array}$ & $\begin{array}{l}\text { Interval } \\
1 \mathrm{~s} / \mathrm{d} 5\end{array}$ \\
\hline
\end{tabular}

\section{Metode Analisis}

Analisis data penelitian menggunakan pendekatan kuantitatif, dengan tahapantahapan sebagai berikut:

1. Melakukan pengujian validitas dan reliabilitas instrumen kuesioner. Pengujian validitas pertanyaan/ 
pernyataan dalam kuesioner menggunakan rumus korelasi Pearson. Sedangkan untuk menguji reliabiltias instrumen digunakan rumus Alpha Cronbach.

2. Melakukan analisis deskriptif dengan tujuan untuk mengetahui gambaran secara umum karakteristik responden dan variabel penelitian, melalui nilai mean, median, mode dan prosentase.

3. Melakukan pengujian normalitas data untuk mengetahui apakah data yang akan diolah dengan statistik parametrik mendekati/mengikuti normal atau tidak. Pengujian normalitas data menggunakan uji statistik Kolmogorov-Smirnov (K-S).

4. Melakukan analisis inferensial untuk menguji hipotesis penelitian. Rumus yang digunakan yaitu : uji beda (t-test) dua sampel yang berkorelasi (Sugiyono, 2004: 119.

\section{HASIL PENELITIAN DAN PEMBAHASAN \\ Hasil Penelitian \\ Karakteristik Responden}

Berdasarkan gender sebagian besar responden berjenis kelamin perempuan yaitu sebesar 59\% sedangkan laki-laki sebesar $41 \%$. Dilihat dari umur sebagian besar responden berumur 18 - 22 tahun sebanyak $61 \%$, responden berumur $23-27$ sebesar $35 \%$ dan responden berumur diatas 27 tahun sebesar $4 \%$. Dilihat dari latar belakang pekerjaan sebagian besar responden sudah bekerja yaitu sebesar $52 \%$ dan yang belum bekerja sebesar $38 \%$, serta responden yang berwirausaha sebesar $10 \%$.

\section{Uji Validititas dan Reliabilitas}

Variabel sikap berwirausaha diukur dengan 10 butir pertanyaan dan kesemuanya dinyatakan valid dengan tingkat reliabilitas (Alpha Cronbach) sebesar 0,822 dan dinyatakan reliabel. Variabel motivasi berwirausaha diukur dengan 10 butir pertanyaan dan kesemuanya dinyatakan valid dengan tingkat reliabiltas (Alpha Cronbach) sebesar 0,875 dan dinyatakan reliabel. Variabel sikap berwirausaha juga diukur dengan 10 butir pertanyaan dan kesemuanya dinyatakan valid dengan tingkat reliabiltas (Alpha Cronbach) sebesar 0,840 dan dinyatakan reliabel.

\section{Deskripsi Variabel Penelitian}

Secara umum rata-rata sikap berwirausaha responden sebelum dan sesudah pembelajaran kewirausahaan mengalami peningkatan sebesar 3,32\% (Mean 39,51 menjadi 41,17). Rata-rata motivasi berwirausaha responden sebelum dan sesudah pembelajaran kewirausahaan juga mengalami peningkatan sebesar 1,42\% (Mean 39,62 menjadi 40,33). Sedangkan rata-rata minat berwirausaha responden sebelum dan sesudah pembelajaran kewirausahaan mengalami peningkatan paling kecil sebesar 0,8\% (Mean 37,11 menjadi 37,51).

\section{Uji Normalitas Data}

Melalui uji Kolmogorov Smirnov data variabel sikap berwirausaha sebelum dan sesudah pembelajaran kewirausahaan dinyatakan terdistribusi normal, masingmasing mempunyai nilai Asyim-Sig sebesar 0,156 dan 0,299 dan nilai keduanya lebih besar dari 0,05. Data variabel motivasi berwirausaha sebelum dan sesudah pembelajaran kewirausahaan mempunyai nilai Asym-Sig masing-masing sebesar 0,440 dan 0,074, nilai keduanya juga lebih besar dari 0,05 yang berarti berdistribusi normal. Nilai Asym-Sig. untuk data variabel minat berwirausaha sebelum dan sesudah pembelajaran kewirausahaan masing-masing 0,408 dan 0,321, yang artinya keduanya berdistribusi normal. 


\section{Pengujian Hipotesis Penelitian}

1. Hipotesis Pertama

Besarnya nilai t-hitung variabel sikap berwirausaha sebelum dan sesudah pembelajaran kewirausahaan sebesar 9,927 dengan probabilitas sebesar 0,000 . Karena nilai probabilitas $t-$ hitung $(0,000)<0,05$, yang berarti perbedaan sikap berwirausaha mahasiswa sebelum dan sesudah mendapatkan pembelajaran kewirausahaan adalah signifikan.

2. Hipotesis Kedua

Besarnya nilai t-hitung variabel motivasi berwirausaha sebelum dan sesudah pembelajaran kewirausahaan sebesar -2,532 dengan probabilitas sebesar 0,012 . Karena nilai probabilitas t-hitung $(0,012)<0,05$, yang berarti perbedaan motivasi berwirausaha mahasiswa sebelum dan sesudah mendapatkan pembelajaran kewirausahaan adalah signifikan.

3. Hipotesis Ketiga

Besarnya nilai t-hitung variabel minat berwirausaha sebelum dan sesudah pembelajaran kewirausahaan sebesar 1,162 dengan probabilitas sebesar 0,247 . Karena nilai probabilitas thitung $(0,247)>0,05$, yang berarti minat berwirausaha mahasiswa sebelum dan sesudah mendapatkan pembelajaran kewirausahaan adalah tidak signifikan.

\section{Pembahasan}

\section{Perbedaan Sikap Berwirausaha Setelah Pembelajaran Kewirausahaan}

Ada perbedaan yang signifikan sikap berwirausaha mahasiswa STIE IPWIJA sebelum dan sesudah pembelajaran kewirausahaan. Pembelajaran kewirausahaan yang yang selama ini dilaksanakan STIE IPWIJA ternyata mampu merubah sikap berwirausaha mahasiswa. Hal ini dapat dilihat dari hasil analisis deskriptif yang mengalami peningkatan perubahan sikap berwirausaha mahasiswa sebesar 3,32\%. Secara deskripsi setelah mengikuti pembelajaran kewirausahaan diperoleh informasi bahwa jumlah mahasiswa yang mengalami peningkatan sikap berwirausaha sebanyak $74,0 \%$, dan sebaliknya sebesar $14,7 \%$ mahasiswa mengalami penuruan sikap berwirausaha serta sebanyak $11,3 \%$ mahasiswa tidak mengalami perubahan sikap berwirausaha. Meskipun prosentase perbedaan perubahan sikap berwirausaha mahasiswa setelah mengikuti pembelajaran kewirausahaan angkanya kecil $(3,32 \%)$, namun setelah diuji secara statistik perbedaan sikap berwirausaha tersebut cukup nyata. Artinya pembelajaran kewirausahaan yang selama ini diberikan kepada para mahasiswa sudah baik dan tepat sasaran. Hasil penelitian ini memperkuat temuan penelitian sebelumnya yang dilakukan oleh Andhika Wahyudiono (2016) dan Satriyanto Wibowo dan Komang Agus Satria Pramudana (2016), yang menyatakan bahwa pendidikan kewirausahaan berpengaruh positip dan signifikan terhadap sikap berwirausaha mahasiswa.

Konsekwensi dari hasil penelitian ini adalah perlunya pembelajaraan kewirausahaan di Perguruan Tinggi lebih ditumbuhkembangkan lebih maksimal sebagai upaya untuk meningkatkan sikap berwirausaha. Dengan meningkatnya sikap berwirausaha maka diharapkan juga akan dapat meningkatkan minat berwirausaha mahasiswa (Winarsih, 2014). Pendidikan kewirausahaan tidak lain adalah bertujuan untuk menyiapkan agar mahasiswa memiliki kesiapan untuk membuka usaha baru setelah lulus kuliah. Dengan demikian diharapkan para lulusan perguruan tinggi lebih menjadi pencipta lapangan kerja dari pada pencari kerja. 


\section{Perbedaan Motivasi Berwirausaha Setelah Pembelajaran Kewirausahaan}

Ada perbedaan yang signifikan motivasi berwirausaha mahasiswa STIE IPWIJA sebelum dan sesudah mendapatkan pembelajaran kewirausahaan. Motivasi seseorang merupakan variabel yang penting dalam memulai berwirausaha. Pentingnya motivasi karena motivasi adalah hal yang menyebabkan, menyalurkan dan mendukung perilaku seseorang supaya mau bekerja lebih giat dan antusias mencapai hasil yang optimal (Hasibuan, 2016). Naik turunnya motivasi seseorang dapat disebabkan beberapa faktor diantaranya keinginan untuk mandiri, kebutuhan, keamanan keluarga, imbalan, faktor intrinsik dan ekstrinsik, pembelajaran dan pelatihan-pelatihan wirausaha. Pembelajaran kewirausahaan yang dilaksanakan STIE IPWIJA selama ini telah mampu merubah motivasi berwirausaha mahasiswa. Hal ini dapat dilihat dari hasil analisis deskriptif yang mengalami peningkatan motivasi berwirausaha mahasiswa sebesar 1,42\%. Secara deskripsi setelah mengikuti pembelajaran kewirausahaan diperoleh informasi bahwa jumlah mahasiswa yang mengalami peningkatan motivasi berwirausaha sebanyak 58,7\%, dan sebaliknya sebesar 35,3\% mahasiswa mengalami penuruan motivasi berwirausaha serta sebanyak 6,0\% mahasiswa tidak mengalami perubahan motivasi berwirausaha. Meskipun prosentase perbedaan perubahan motivasi berwirausaha mahasiswa setelah mengikuti pembelajaran kewirausahaa angkanya sangat kecil (1,42\%), namun setelah diuji secara statistik perbedaan motivasi berwirausaha tersebut cukup signifikan. Artinya pembelajaran kewirausahaan yang selama ini diberikan kepada para mahasiswa sudah baik dan tepat sasaran. Hasil penelitian ini mendukung hasil penelitian sebelumnya yang dilakukan oleh Reza Fahmi (2012), Muhammad Zainul Majdi (2012) yang menyimpulkan bahwa terdapat pengaruh positif dan signifikan pembelajaran kewirausahaan dengan motivasi berwirausaha mahasiswa. Demikian juga penelitian yang dilaksanakan oleh Darpujianto (2014) yang menghasilkan temuan bahwa kelompok mahasiswa yang memperoleh pembelajaran kewirausahaan ada peningkatan motivasi berwirausaha yang signifikan antara sebelum dan sesudah pembelajaran kewirausahaan.

Konsekwensi dari hasil penelitian ini adalah perlunya materi pembelajaran kewirausahaan didesain dan disajikan semenarik mungkin sehingga dapat menggugah dan memotivasi para mahasiswa. Dengan meningkatkan motivasi mahasiswa dalam berwirausaha maka diharapkan akan merubah mindset mahasiswa dalam berwirausaha. Pembelajaraan kewirausahaan dalam upaya untuk meningkatkan motivasi mahasiswa untuk berwirausaha memerlukan: pengetahuan, ketrampilan, sikap yang akhirnya menumbuhkan perilaku berwirausaha yang dipengaruhi faktor internal dan eksternal. Motivasi ekternal dapat ditumbuhkan dengan cara memperkenalkan dan berhubungan langsung dengan tokoh-tokoh sukses dibidang kewirausahaan, sehungga para mahasiswa dapat meneladani sikap-sikap positip yang dimiliki para tokoh sukses tersebut.

\section{Perbedaan Minat Berwirausaha Setelah Pembelajaran Kewirausahaan}

Tidak ada perbedaan yang signifikan minat berwirausaha mahasiswa STIE IPWIJA sebelum dan sesudah pembelajaran kewirausahaan. Berdasarkan hasil analisis deskriptif 
peningkatan perubahan minat berwirausaha mahasiswa sebelum dan sesudah mengikuti pembelajaran kewirausahan memang sangat kecil. Hal ini dapat dilihat perbandingan nilai ratarata sebelum dan sesudah mengikuti pembelajaran kewirausahaan yaitu 37,11 dan 37,51 atau hanya ada peningkatan sebesar 0,8\%. Secara deskripsi setelah mengikuti pembelajaran kewirausahaan diperoleh informasi bahwa jumlah mahasiswa yang mengalami peningkatan motivasi berwirausaha sebanyak 55,3\%, dan sebaliknya sebesar 36,0\% mahasiswa mengalami penuruan minat berwirausaha serta sebanyak 8,7\% mahasiswa tidak mengalami perubahan minat berwirausaha. Setelah dilakukan pengujian secara statistik perbedaan motivasi berwirausaha sebelum dan sesudah mengikuti pembelajaran kewirausahaan hasilnya tidak ada perbedaan yang signifikan. Meskipun pembelajaran kewirausahaan yang selama ini diberikan kepada para mahasiswa berdampak terhadap perubahan sikap dan motivasi berwirausaha mahasiswa, namun sebaliknya pembelajaran kewirausahaan tidak berdampak terhadap minat mahasiswa dalam berwirausaha. Penulis punya dugaan yang kuat bahwa tidak terbuktinya hipotesis yang ketiga ini kemungkinan disebabkan oleh adanya sebagian besar mahasiswa STIE IPWIJA saat ini sudah bekerja dan sudah mempunyai usaha sendiri. Hal ini dapat dibuktikan bahwa sebanyak 52\% mahasiswa STIE IPWIJA sudah bekerja dan sebanyak $10 \%$ sudah mempunyai usaha sendiri dan yang belum bekerja hanya sebesar $38 \%$.

Hasil penelitian tersebut memperkuat penelitian sebelumnya yang dilakukan oleh Hendra Wiyanto (2012), yang menyimpulkan bahwa tidak ada perbedaan pada minat wirausaha sebelum dan sesudah pendidikan kewirausahaan, sehingga tidak adanya peningkatan minat wirausaha peserta didik setelah mengikuti pendidikan kewirausahaan. Penelitian lain yang dilakukan oleh Retno Budi Lestasi dan Trisnadi Wijaya (2012), Paulus Patria Adhitama (2014), Utin Hermina, dkk. (2011) dan Anwar Daniel (2017) yang menghasilkan temuan berbeda bahwa pembelajaran kewirausahaan memiliki pengaruh positif dan signifikan terhadap minat berwirausaha mahasiswa, artinya semakin baik pembelajaran kewirausahaan maka akan semakin meningkatakan minat berwirausaha.

Konsekwensi dari hasil penelitian ini bahwa minat berwirausaha tidak dipengaruhi oleh adanya pembelajaran kewirausahaan menjadi perdebatan (polemik). Sepintas hasil penelitian ini sesuai pandangan tradisional yang beranggapan bahwa kewirausahaan itu bakat dari lahir dan karenanya tidak dapat diajarkan. Namun beberapa studi empiris menemukan bahwa kewirausahaan dapat diajarkan, diantaranya melalui pendekatan action based learning, experiental learning dan consultation-based learning (Agus Siswanto, 2012).

Pada kenyataannya bahwa minat berwirausaha tidak serta merta hanya dipengaruhi oleh faktor tunggal saja, tetapi banyak faktor yang dapat mempengaruhi minat mahasiswa dalam berwirausaha, diantaranya faktor lingkungan keluarga, ekspektasi pendapatan (Paulus Patria Adhitama, 2014), penggunaan media sosial (Eswanto Sugeng Rahayu, 2018).

\section{KESIMPULAN}

Berdasarkan hasil penelitian dan pembahasan diatas dapat dibuat kesimpulan sebagai berikut:

1. Ada perbedaan sikap berwirausaha mahasiswa STIE IPWIJA sebelum dan 
sesudah mendapatkan pembelajaran kewirausahaan.

2. Ada perbedaan motivasi berwirausaha mahasiswa STIE IPWIJA sebelum dan sesudah mendapatkan pembelajaran kewirausahaan.

3. Tidak ada perbedaan minat berwirausaha mahasiswa STIE IPWIJA sebelum dan sesudah mendapatkan pembelajaran kewirausahaan.

\section{SARAN}

1. Materi pembelajaran kewirausahaan hendaknya disusun lebih fleksibel dan adaftif untuk menyesuaikan perkembangan teknologi yang cepat.

2. Dengan cara memperkenalkan dan berhubungan langsung dengan tokohtokoh sukses dibidang kewirausahaan diharapkan para mahasiswa akan dapat meneladani sikap-sikap positip yang dimiliki para tokoh sukses tersebut.

3. Materi pembelajaran kewirausahaan hendaknya didesain dan disajikan semenarik mungkin sehingga dapat menggugah dan memotivasi para mahasiswa untuk berwirausaha.

4. Perlu dilakukan penelitian yang serupa dengan lingkup yang lebih luas lagi dengan melibatkan beberapa perguruan tinggi lain agar hasilnya lebih obyektif.

\section{DAFTAR PUSTAKA}

Adhitama, Paulus Patria. (2014). "FaktorFaktor Yang Mempengaruhi Minat Berwirausaha (Studi Kasus Mahasiswa Fakultas Ekonomi dan Bisnis UNDIP Semarang)". Skripsi. Universitas Diponegoro.

Alma, Buchori. (2013). Kewirausahaan. Penerbit Alfabeta, Bandung.

Badan Pusat Statistik. (2018). Agustus 2018: Tingkat Pengangguran Terbuka (TPT) Sebesar 5,34 persen. https://www.bps.go.id/pressrelease/
2018/11/05/1485. Diakses 12 Maret 2019.

CNN Indonesia. (2018). Hanya 3,1 Persen Penduduk Produktif di RI yang Wirausaha. https://www.cnnindonesia.com/eko nomi/20181018210657-92-339664.

Diakses 12 Maret 2019.

Daniel, Anwar dan Dwihartanti, Muslikhah. (2017). "Pengaruh Proses Pembelajaran Kewirausahaan dan Karakter Wirausaha Mahasiswa Prodi Pendidikan Adminidtrasi Perkantoran Universitas Negeri Yogyakarta Tahun Akademik 2015". Jurnal Administrasi Perkantoran Vol. 6 No. 1, Februari 2017. Hal : 38-48

Darpujianto. (2014). "Pengaruh Pembelajaran Kewirausahaan Terhadap Motivasi Berwirausaha Pada Mahasiswa STIE dan SMIK "ASIA" Malang". Jurnal JIBEKA Vol. 8 No. 1, Februari 2014. Hal : 21-30.

Fahmi, Reza. (2012). "Pengaruh Pembelajaran Kewirausahaan Terhadap Motivasi Berwirausaha". Jurnal SHARE Vol. 1 No. 2, Desember 2012. Hal : 99-117

Fu'adi, Iski Fadli, dkk. (2009). "Hubungan Minat Berwirausaha Dengan Praktik Kerja Industri Siswa Kelas XII Teknik Otomatif SMK Negeri Adiwerna Kabupaten Tegal". Jurnal PTM. Vol. 9 No. 2, Desember 2009. Hal : 92-98.

King, Laura A. (2010). Psikologi Umum Sebuah Pandangan Apresiatif The Science Of Psychology - An Appreciative View. Penerbit Salemba Humanika, Jakarta

Hendro. (2011). Dasar-Dasar Kewirausahaan Panduan bagi Mahasiswa untuk Mengenal, Memahami, dan Memasuki Dunia Bisnis. Penerbit Erlangga, Jakarta.

Hermina, Utin Nina dkk. (2011). "Pengaruh Mata Kuliah Kewirausahaan Terhadap Minat Mahasiswa Menjadi Wirausaha Pada Program Studi Administrasi Bisnis Politeknik Negeri Pontianak". Jurnal Eksos Vol. 7 No. 2, Juli 2012. Hal: 130-141. 
Lestari, Retno Budi dan Wijaya, Trisnadi (2012). "Pengaruh Pendidikan Kewirausahaan Terhadap Minat Berwirausaha di STIE MDP, STMIK MDP dan STIE MUS"I. Forum Bisnis Dan Kewirausahaan Jurnal IImiah STIE MDP Vol. 1 No. 2, Maret 2012. Hal : $112-119$. Majdi, Muhammad Zainul. (2012). "Pengaruh Pembelajaran Kewirausahaan, Internalisasi Nilai Kewirausahaan di Keluarga dan Motivasi Minat Kewirausahaan". Jurnal Educatio Vol. 7 No. 2, Desember 2012. Hal : 1 - 25.

Mar'at. (2000). Sikap Manusia, Perubahan, serta Pengukurannya. Penerbit Ghalia Indonesia, Jakarta

Mustofa, Muhammad Arif. (2014). "Pengaruh Pengetahuan Kewirausahaan, Self Efficacy dan Karakter Wirausaha Terhadap Minat Berwirausaha pada Siswa Kelas XI SMK N 1 Depok Kabupaten Sleman". Skripsi. Universitas Negeri Yogyakarta

Rahayu, Eswanto Sugeng dan Laela, Siti (2018). "Pengaruh Minat Berwirausaha dan Penggunaan Sosial Media Terhadap Kewirausahaan Mahasiswa". Jurnal Pengembangan Wiraswasta Vol. 20 No. 3 Tahun 2018. Hal : 203-216

Saiman, Leonardus. (2009). Kewirausahaan: Teori, Praktik, dan Kasus-kasus. Penerbit Salemba Empat, Jakarta

Satriyono, Wibowo dan Pramudana, Komang Agus Satria. (2016). "Pengaruh Pendidikan Kewirausahaan Terhadap Intensi Berwirausaha Yang Dimediasi oleh Sikap Berwirausaha". Junal Manajemen Unud Vol. 5 No. 12 , Tahun 2016. Hal : 8167-8198.

Shane, S., Locke, E. A. \& Collins, C.J. (2003). "Entrepreneurial Motivation". Human Resource Management Review, Vol. 13, pp. 257-279.

Slameto. (2003). Belajar dan Faktor-faktor yang Mempengaruhinya. Penerbit Rineka Cipta, Jakarta
Sugiyono. (2004). Statistik Untuk Penelitian. Penerbit CV Alfabeta, Bandung

Sugiyono. (2010). Metode Penelitian Bisnis. Penerbit CV Alfabeta, Bandung

Suryabrata, Sumadi. (2002). Metodologi Penelitian. Penerbit PT. Raja Grafindo Persada, Jakarta

Suryana. (2011). Kewirausahaan Pedoman Praktis: Kiat dan Proses Menuju Sukses. Penerbit Salemba Empat, Jakarta

Suryana, Yuyus dan Kartib, Bayu, (2010). Kewirausahaan, Pendekatan Karakteristik Wirausahawan Sukses. Penerbit Kencana, Jakarta

Umar, Husein. (2007). Metode Penelitian Untuk Skripsi Dan Tesis Bisnis. Penerbit PT. Raja Grafindo Persada, Jakarta

Universitas Gadjah Mada. (2011). Penting, Pembelajaran Kewirausahaan di Perguruan Tinggi. https://ugm.ac.id/id/newsPdf/3324. Diakses 15 Maret 2019.

Wahyono, Budi dkk. (20140). Pengaruh Pendidikan Kewirausahaan Terhadap Niat Berwirausaha Siswa SMK Negeri 1 Pedan Tahun 2013. https://pdfs.semanticscholar.org/aa 63

Wahyudiono, Andhika. (2016). "Pengaruh Pendidikan Kewirausahaan, Pengalaman Berwirausaha dan Jenis Kelamin Terhadap Sikap Berwirausaha Pada Mahasiswa Fakultas Ekonomi Universitas Muhammadiyah Surabaya". Jurnal Ekonomi Pendidikan dan Kewirausahaan Vol. 4 No. 1, Tahun 2016. Hal : 76-91.

Walgito, Bimo. (1999). Psikologi Sosial. Penerbit Andi, Yogyakarta.

Wiyanto, Hendra. (2012). "Efektivitas Pembelajaran Kewirausahaan Terhadap Minat Wirausaha Peserta Didik Universitas XYZ". Jurnal Manajemen Vol. 16 No. 3, Oktober 2012. Hal : 378-388. 